medRxiv preprint doi: https://doi.org/10.1101/2020.08.24.20180729; this version posted August 26, 2020. The copyright holder for this preprint (which was not certified by peer review) is the author/funder, who has granted medRxiv a license to display the preprint in It is made available under a CC-BY-ND 4.0 International license.

\title{
Convalescent Plasma in treatment of COVID-19: A review of evidence for a living systematic benefit-risk assessment
}

Miranda Davies ${ }^{1,2}$ BM

Samantha Lane ${ }^{1,2}$ MSc

Alison Evans ${ }^{1,2} \mathrm{PhD}$

Jacqueline Denyer ${ }^{1} \mathrm{BA}$

Sandeep Dhanda ${ }^{1,2}$ MB ChB MSc

Debabrata Roy ${ }^{1,2} \mathrm{PhD}$

Vicki Osborne ${ }^{1,2} \mathrm{PhD}$

Saad Shakir ${ }^{1,2}$ MB ChB LRCP\&S FRCP FFPM FISPE MRCGP

1. Drug Safety Research Unit, Southampton, UK

2. School of Pharmacy and Biomedical Sciences, University of Portsmouth, Portsmouth, UK 
medRxiv preprint doi: https://doi.org/10.1101/2020.08.24.20180729; this version posted August 26, 2020. The copyright holder for this

preprint (which was not certified by peer review) is the author/funder, who has granted medRxiv a license to display the preprint in It is made available under a CC-BY-ND 4.0 International license.

\section{Abstract}

Objectives: We aimed to review the evidence for a living systematic benefit risk assessment for convalescent plasma use amongst patients with severe COVID-19 disease, based on currently available data.

Methods: The assessment used the Benefit-Risk Action Team (BRAT) framework. Convalescent plasma treatment in severe COVID-19 was compared to standard of care, placebo or other treatments. A literature search was conducted to identify published papers from January $1^{\text {st }}, 2019$ until July $8^{\text {th }}, 2020$. A value tree was constructed which included ranked key benefits and risks.

Results: We screened 396 papers from PubMed and 127 papers from Embase. Four studies were eligible for inclusion as they contained comparative data. Results from a randomised controlled trial revealed a non-statistically significant shortening of time to clinical improvement of 2.15 days ( $95 \%$ CI,-5.28 to 0.99 days) in the intervention group compared with the control group, with a possible signal of increased efficacy amongst a small subset of patients with severe disease (but not life threatening disease), however this study may have been underpowered. Interpretation of findings amongst the three controlled nonrandomised studies were limited by small patient numbers, lack of randomisation, and confounding by co-administration of other treatments. Limited data availability at the current time precluded construction of a data summary table and further quantitative analysis.

Conclusions: There was insufficient evidence from controlled studies to complete a data summary table for a systematic benefit-risk assessment of the use of CP for severe COVID19 disease at the current time, and as such a benefit-risk conclusion could not be made. Whilst uncontrolled case series have suggested positive findings with $\mathrm{CP}$, results from these studies are very difficult to interpret. We provide a framework which can be updated when further data that have an impact on the benefit-risk become available. 
medRxiv preprint doi: https://doi.org/10.1101/2020.08.24.20180729; this version posted August 26, 2020. The copyright holder for this

preprint (which was not certified by peer review) is the author/funder, who has granted medRxiv a license to display the preprint in It is made available under a CC-BY-ND 4.0 International license.

\section{Article Summary}

Strengths and limitations of this study

- provides a living systematic benefit risk assessment based on currently available data for the use of convalescent plasma in patients with severe COVID-19 disease

- establishes a framework inclusive of ranked key benefits and risks for convalescent plasma in severe COVID-19 disease, into which additional data can be added as this becomes available facilitating re-assessment of the benefit risk profile

- uses a transparent framework (BRAT framework) which can be applied to other potential treatment options in this disease context

- insufficient data available at the current time from comparative studies to form a benefit risk conclusion

\section{Introduction}

The novel coronavirus subsequently called Severe Acute Respiratory Syndrome coronavirus 2 (SARS-CoV-2) which causes coronavirus disease (COVID-19) led to the World Health Organisation declaring a pandemic in March 2020 [1]. Whilst the majority of cases of COVID-19 are mild, there is an increase in the infection mortality ratio with increasing age, with the highest mortality risk amongst people aged $\geq 80$ years [2]. Since the start of the pandemic, intensive worldwide scientific research has been conducted in a bid to identify safe, effective treatment options as quickly as possible. So far, remdesivir is the first treatment for COVID-19 to be recommended for authorisation in the European Union [3]. The European Medicines Agency is currently reviewing results from the RECOVERY study arm that involved the use of dexamethasone in the treatment of patients with COVID-19 admitted to hospital [4].

Convalescent plasma (CP) treatment, in which plasma containing antibodies is collected from patients who have recovered from COVID-19, is another treatment option currently being investigated. Two systematic reviews and exploratory meta-analyses included results for patients with respiratory infections of viral aetiology such as SARS-CoV and influenza virus who received $\mathrm{CP}[5,6]$ and one of these included four studies inclusive of patients with SARS-CoV-2 [6]. Results suggested that CP may reduce mortality and would appear to be well tolerated with larger treatment effects if commenced early after symptom onset $[5,6]$. In the US, on March 24 ${ }^{\text {th }}, 2020$, the Food and Drug Administration (FDA) announced an emergency Investigational New Drug (IND) process to allow individual physicians to treat 
medRxiv preprint doi: https://doi.org/10.1101/2020.08.24.20180729; this version posted August 26, 2020. The copyright holder for this preprint (which was not certified by peer review) is the author/funder, who has granted medRxiv a license to display the preprint in It is made available under a CC-BY-ND 4.0 International license.

patients with serious COVID-19 disease with CP. On April $7^{\text {th }}$, 2020, the FDA announced a National Expanded Access Protocol administered through the Mayo Clinic. The protocol enabled a wider range of adults to be treated with $\mathrm{CP}$ by including those at risk of severe disease as well as those already suffering from severe disease [7]. On April $8^{\text {th }} 2020$, the European Commission recommended that transfusion of COVID-19 CP, as an immediately available experimental therapy with low risk, should be considered as an urgent priority and its outcome monitored [8]. In addition to access to this treatment through compassionate use programmes, there are currently multiple RCTs being conducted across the world; as of June $30^{\text {th }}$ 2020, there were 113 studies involving CP, including expanded access programmes, registered on the clinical trials.gov website [9]. In the UK, the National Health Service Blood and Transplant (NHSBT) service is supporting two major clinical trials, RECOVERY and REMAP-CAP [10]. In the REMAP-CAP trial, CP treatment is indicated for people who have been in intensive care for less than 48 hours and have tested positive for COVID-19, whilst in the RECOVERY trial the effectiveness of CP is examined for patients with COVID-19 who are in hospital, but not in intensive care [10].

To date two systematic reviews have been conducted to assess the evidence in support of the use of CP in COVID-19. Rajendran and colleagues evaluated the effectiveness of CP transfusion (CPT) therapy in COVID-19 patients and concluded that in addition to antiviral/antimicrobial drugs, CPT could be an effective therapeutic option [11]. This review included five studies inclusive of 27 patients. More recently a living Cochrane systematic review by Valk and colleagues (published May $14^{\text {th }} 2020$ ) aimed to assess effectiveness and safety of CP or hyperimmune immunoglobulin transfusion in COVID-19 [12]. Valk et al concluded that there was very low-certainty evidence on the effectiveness and safety of $\mathrm{CP}$ therapy for people with COVID-19 based on the data available at that time. However, a systematic benefit-risk assessment on the use of CP for COVID-19 treatment, based on currently available evidence, has not yet been conducted.

The Benefit-Risk Action Team (BRAT) uses a structured, descriptive framework to outline the key benefits and risks of a medication within a defined disease context. If sufficient relevant data are available, additional quantitative assessment can be used to further examine the benefit-risk profile [13]. Importantly, the framework improves transparency and consistency in the decision-making process and allows the robustness of any assumptions used in the assessment to be further explored using sensitivity analyses [14]. The method is dynamic, meaning that further data can be easily incorporated into the platform as this becomes available, and has been designed to assist communication with regulatory authorities [15], 
medRxiv preprint doi: https://doi.org/10.1101/2020.08.24.20180729; this version posted August 26, 2020. The copyright holder for this

preprint (which was not certified by peer review) is the author/funder, who has granted medRxiv a license to display the preprint in It is made available under a CC-BY-ND 4.0 International license .

in addition to clinicians and public health bodies in the decision-making process on treatments for COVID-19. Benefit-risk assessments using this methodology in the context of severe COVID-19 disease have previously been applied to the anti-viral drug remdesivir [16] and the protease inhibitors lopinavir/ritonavir [17].

\section{$2 \quad$ Objectives}

The main objective of this study was to examine the benefit-risk profile of CP in COVID-19 patients compared to standard of care, placebo or other treatments. A key objective of this study was to provide a platform for a living systematic benefit-risk evaluation. Although initially this evaluation is likely to contain limited information, it is required due to the urgent unmet public need. Importantly it allows additional data to be incorporated as it becomes available, and re-evaluation of the benefit-risk profile.

\section{$3 \quad$ Methods}

\subsection{Benefit-Risk framework}

The BRAT framework was used to assess the overall benefit-risk of using CP as a treatment for COVID-19 compared to standard of care, placebo or other treatments. BRAT uses a sixstep iterative process to support the decision and communication of a benefit-risk assessment: define decision context, identify outcomes, identify data sources, customise framework, assess outcome importance, and display and interpret key Benefit-Risk metrics [15]. Multiple settings for the use of $\mathrm{CP}$ are being investigated including high-risk individuals for prophylaxis, patients with mild disease, those with serious but not critical disease, intensive care unit (ICU) patients, or children. This assessment focuses on CP for the treatment of severe COVID-19 disease, which we defined as hospitalisation as a result of COVID-19 infection.

\subsubsection{Population of interest}

Patients with severe COVID-19 who were treated with CP were the population of interest, while patients receiving standard of care, placebo or other treatments were the comparator of interest. Where standard of care was reported as the comparator group, this refers to no use of a specific pharmaceutical treatment for COVID-19 but provision of standard supportive therapy within the hospital setting.

\subsubsection{Identification of outcomes of interest - the value tree}


medRxiv preprint doi: https://doi.org/10.1101/2020.08.24.20180729; this version posted August 26, 2020. The copyright holder for this

preprint (which was not certified by peer review) is the author/funder, who has granted medRxiv a license to display the preprint in It is made available under a CC-BY-ND 4.0 International license.

Key benefits and risks were selected based on clinician judgement, i.e. those considered to be of clinical importance or potentially serious, and a visual representation of those key outcomes have been provided in a value tree. Key benefits and risks associated with the use of CP were identified for inclusion in the value tree from all available data sources, including the product information, regulatory assessment reports, and published literature. Key benefits (clinical endpoints) were derived from both published literature and in the case of ongoing studies, available clinical trial protocols. These benefits and risks, as presented in the value tree, were derived from both qualitative and quantitative data, and ranked according to perceived importance (benefits) and potential seriousness (risks). Two clinicians performed this ranking after discussion of the clinical significance of each benefit and risk.

\subsubsection{Data sources and customisation of the framework}

A literature search was performed in PubMed and Embase using the following search strategy:

((plasma OR "blood plasma" OR "convalescent plasma") AND (covid* OR SARS-CoV-2 OR (n-CoV OR nCoV) OR coronavirus)). Manuscripts were reviewed for eligibility and a clinical reviewer made the final decision on inclusion. Results were restricted to English language only (abstracts in English language were acceptable where sufficient data provided) and peer-reviewed publications since January $1^{\text {st }}, 2019$ to July $8^{\text {th }}, 2020$.

\subsection{Outcome assessment}

Where sufficient numerical data is available, a summary benefit-risk table allows visualisation of the magnitude of each benefit and risk. Risk differences and corresponding 95\% confidence intervals (CI) are calculated for each outcome where both numerator (number of events) and denominator (number of patients at risk) are available for both the treatment group (CP) and comparator group. Since there was insufficient evidence for use of CP in COVID-19, quantitative outcome assessment was not undertaken.

\section{Patient and Public Involvement (PPI) statement}

There were no funds or time allocated for PPI so we were unable to involve patients. 
medRxiv preprint doi: https://doi.org/10.1101/2020.08.24.20180729; this version posted August 26, 2020. The copyright holder for this

preprint (which was not certified by peer review) is the author/funder, who has granted medRxiv a license to display the preprint in It is made available under a CC-BY-ND 4.0 International license .

\subsection{Results}

From literature searching we identified 396 papers from PubMed and 127 papers from Embase for CP. All papers were reviewed for information on benefits and risks relating to $\mathrm{CP}$, including both qualitative and quantitative data. After initial review and removal of duplicates, 86 papers were identified with information on safety of CP and 19 papers with efficacy information for $\mathrm{CP}$. These papers were reviewed further to determine whether they contained comparative data; only four papers compared CP to standard of care, placebo or other treatments.

Figure 1 displays the value tree of the key benefits and risks related to $\mathrm{CP}$ treatment in COVID-19. It is acknowledged that certain outcomes, such as mortality risk, could be considered as either a benefit (reduction in mortality risk) or a risk (increase in mortality risk) of CP treatment. As mortality risk is an important clinical endpoint in many COVID-19 trials, for the purposes of this assessment mortality risk has been considered under potential benefits. Risks have been classified as known risks and theoretical risks. The evidence for theoretical risks has arisen from knowledge of adverse effects observed with other viral diseases, including influenza, respiratory syncytial virus and SARS-CoV.

\section{Figure 1 Value Tree}

\subsection{Benefits}

Key benefits have been listed in the value tree in descending order of perceived clinical importance. Multiple case series have published findings following the use of CP amongst patients with COVID-19 [18-23]. Findings from these would appear to be encouraging, however interpretation is limited by the lack of a comparator group, the small number of patients, and confounding by co-administration of other COVID-19 treatments. As per the methodology for this benefit-risk assessment, only studies which included a control group were evaluated further. At the current time, we identified four comparative studies.

The first was an open label RCT conducted by Li et al (published June $3^{\text {rd }} 2020$ ) which included 103 participants with laboratory confirmed COVID-19 that was severe (respiratory distress and /or hypoxemia) or life-threatening (shock, organ failure, or requiring mechanical ventilation) [24]. Two treatment arms consisted of patients treated with CP plus standard treatment $(n=52)$ vs. standard treatment alone (control) $(n=51)$. The primary outcome was time to clinical improvement within 28 days, defined as patient discharged alive or reduction of two points on a 6-point disease severity scale. Secondary outcomes 
medRxiv preprint doi: https://doi.org/10.1101/2020.08.24.20180729; this version posted August 26, 2020. The copyright holder for this

preprint (which was not certified by peer review) is the author/funder, who has granted medRxiv a license to display the preprint in It is made available under a CC-BY-ND 4.0 International license .

included 28-day mortality, time to discharge, and the rate at which viral polymerase chain reaction (PCR) results turned from positive at baseline to negative at up to 72 hours. The target sample size was 200 patients; however the trial was terminated early due to a lack of patients and may have been underpowered. Study findings overall showed a non-statistically significant shortening of time to clinical improvement of 2.15 days ( $95 \%$ CI, -5.28 to 0.99 days) in the intervention group compared with the control group. Overall, clinical improvement at 28 days occurred in 27 patients (51.9\%) in the intervention group vs. 22 patients (43.1\%) in the control group (difference, $8.8 \%$; $95 \% \mathrm{CI},-10.4 \%$ to $28 \%$ ). Amongst patients with severe disease, time to clinical improvement within 28 days was 4.94 days shorter ( $95 \% \mathrm{CI},-9.33$ to -0.54 days) in the intervention group compared with the control group, and clinical improvement at 28 days occurred in 21 patients (91.3\%) in the intervention group vs. 15 patients (68.2\%) in the control group (difference, $23.1 \%(-3.9 \%$ to $50.2 \%$ ). This is in contrast to patients with life threatening disease, in which there were no significant differences in the primary outcome or rates of clinical improvement at 28 days. Overall, no statistically significant differences were observed for any of the secondary clinical endpoints, however statistically significant differences were seen for rate of viral PCR conversion at up to 72 hours [viral nucleic acid negative rate at $72 \mathrm{~h}$ (intervention group, $41 / 47(87.2 \%)$ control group, $15 / 40$ (37.5\%), difference $49.7 \%$ (32.0\% to $67.5 \%)$ Odds Ratio (OR), $11.39(3.91-33.18) \quad \mathrm{p}<.001]$.

More recently (published June $19^{\text {th }}$ 2020), Hegerova and colleagues reported the findings from a controlled non-randomised study in which results for 20 hospitalized patients treated with CP were compared to 20 matched controls with severe or life-threatening COVID-19 infection [25]. Patients' clinical status was assessed using the WHO ordinal scale, and results suggested that clinical status at 14 days follow up was similar in both groups. A similar number of patients in each group were discharged home at 14 days (45\%), whilst results showed a lower mortality risk at 14 days amongst the CP patients $(2 / 20,10 \%)$ compared to controls $(6 / 20,30 \%)$. No adverse events were reported in the CP group, although the risk in both groups of venous thrombosis at 14 days follow up was $20 \%$ [25]. Additional therapies for COVID-19 were also received by patients in both groups.

A further observational study conducted by Zeng et al (published April 28 $8^{\text {th }} 2020$ ), retrospectively analysed the clinical outcomes of 21 patients who required ICU admission, of whom six patients received CP treatment, and compared clinical outcomes to the 15 patients who did not receive $\mathrm{CP}$. The findings from this study suggested that all six patients who received $\mathrm{CP}$ achieved viral clearance compared to a quarter of patients who did not receive 
medRxiv preprint doi: https://doi.org/10.1101/2020.08.24.20180729; this version posted August 26, 2020. The copyright holder for this preprint (which was not certified by peer review) is the author/funder, who has granted medRxiv a license to display the preprint in It is made available under a CC-BY-ND 4.0 International license.

$\mathrm{CP}[4 / 15,26.7 \%]$, however fatality rates were similar in both groups of patients $[83.3 \%$, $93.3 \%, p=0.5]$. The authors state that failure of $\mathrm{CP}$ to reduce the mortality may be attributed to the late transfusion of $\mathrm{CP}$ (median duration of viral shedding before treatment was 21.5 days) [26].

The fourth comparative study by Duan et al (published April $6^{\text {th }} 2020$ ) was a prospective non-randomised study in which outcomes were compared between ten patients with critical COVID-19 who received convalescent plasma (plus standard therapy) and ten historic control patients [27]. The historic controls were matched for age, gender and severity of disease, and received standard therapy. The primary endpoint was the safety of CP transfusion, whilst secondary endpoints included the improvement of clinical symptoms and laboratory and radiological parameters within three days after CP transfusion. Outcome data presented in a supplementary appendix revealed no reported deaths amongst patients who received CP compared to three deaths reported amongst control patients (30\%) [28].

Favourable results were observed with respect to the proportion of patients with improvement in clinical status and the proportion discharged following CP compared to controls. However, limitations to interpretation of results included the small sample size and lack of adjustment for additional confounding factors. Furthermore, the period of follow up during which outcomes, including mortality, were assessed was limited to three days post transfusion whilst the follow up period was not clear amongst control patients. Therefore follow up period was short, and it is not known whether follow up periods for both groups were comparable. Whilst no serious adverse reactions or safety events were recorded after $\mathrm{CP}$ transfusion, AEs were not reported for the control group.

\subsection{Risks}

The key risks identified in the value tree were identified from a range of data sources and ranked according to perceived seriousness. The incidence of the transfusion reactions included in the value tree have been described in an unpublished report by the US FDA Expanded Access Program for COVID-19, based on the first 20,000 hospitalized patients transfused with CP [29]. Treating physicians evaluated relatedness, and transfusion-related serious adverse events (SAEs) were independently adjudicated. One hundred and forty-six SAEs classified as transfusion reactions were reported ( $<1 \%$ of all transfusions). Transfusion related reactions included transfusion associated circulatory overload (TACO), transfusionrelated acute lung injury (TRALI), and severe allergic transfusion reactions. The report also classified mortality that occurred within four hours of transfusion as a transfusion associated reaction. Amongst transfusion related reactions, TACO was reported at an incidence of 
medRxiv preprint doi: https://doi.org/10.1101/2020.08.24.20180729; this version posted August 26, 2020. The copyright holder for this

preprint (which was not certified by peer review) is the author/funder, who has granted medRxiv a license to display the preprint in It is made available under a CC-BY-ND 4.0 International license.

$0.18 \%(95 \%$ CI $0.13 \%, 0.25 \%)$ followed by severe allergic transfusion reaction $(0.13 \%$ (95\% CI $0.09 \%, 0.19 \%)$ ), and TRALI (0.10\% (95\% CI 0.06\%, 0.15\%)). Mortality within four hours of transfusion that was assessed as related was reported in 13 patients $(0.06 \%$ (95\% CI 0.04\%, 0.11\%)) [29].

This study also described the incidence of thrombotic and cardiac events. Within seven days of completion of the COVID-19 CP transfusion, 1,136 other SAEs were reported. Of these SAEs, 87 thromboembolic or thrombotic events were reported, 406 sustained hypotensive events requiring intravenous pressor support were reported, and 643 patients suffered a cardiac event. Notably, the vast majority of the thromboembolic or thrombotic complications $(n=55)$ and cardiac events $(n=569)$ were judged to be unrelated to the plasma transfusion. The authors state that in aggregate, adverse cardiac events occurred in 3\% of patients transfused with COVID-19 CP. The vast majority of adverse cardiac events of interest (88\%) were deemed unrelated to the plasma transfusion by the treating physicians. Overall, there was insufficient evidence to suggest that thrombotic and cardiac events were potential risks associated with CP and hence neither of these events have been included in the value tree. However, it is acknowledged that plasma naturally contains procoagulants [30] and the effects of these in the context of COVID-19 disease with respect to risk of thrombotic events is currently not known.

There are additional risks associated with transfusions including infectious disease transmission, however this has been much reduced in recent decades due to donor screening and testing [31], hence this risk is considered to be low, but may vary between countries. The risk of haemolytic transfusion reactions is similarly considered to be low, as transfusion services provide blood group $A B O$ compatible fresh frozen plasma to patients [31].

An additional potential risk of CP transfusion includes the development of antibodydependent enhancement (ADE), which has been previously recognised in other viral illnesses $[32,33]$. It is characterized as either the facilitation of viral entry into cells by antibody or the enhancement by antibody of viral toxicity [34]. A further related risk is complementdependent antibody enhancement, which has also been seen in other viral illnesses such as Ebola, and it is not yet known whether this plays a role in COVID-19 [34]. Theoretically the administration of antibodies to those exposed to SARS-CoV-2 may prevent COVID-19 disease in a manner that reduces the immune response, possibly leaving such individuals vulnerable to subsequent reinfection [35]. 
medRxiv preprint doi: https://doi.org/10.1101/2020.08.24.20180729; this version posted August 26, 2020. The copyright holder for this

preprint (which was not certified by peer review) is the author/funder, who has granted medRxiv a license to display the preprint in It is made available under a CC-BY-ND 4.0 International license.

In the RCT by Li et al, two participants reported transfusion-related adverse events following CP transfusion. One patient in the severe COVID-19 group developed a non-severe allergic transfusion reaction and also a probable non-severe febrile non-haemolytic transfusion reaction. The other patient, who was in the life-threatening COVID-19 group, developed possible severe transfusion-associated dyspnoea. No SAEs were reported in the three controlled non-randomised studies [25-27].

\subsection{Quantitative data}

Due to the lack of available efficacy and safety data available from comparative studies it was not possible to perform further quantitative analysis.

\section{Discussion}

The primary objective of this study was to perform a living systematic benefit-risk assessment of the use of CP for the treatment of severe COVID-19 disease, using methodology previously published $[13,16,17]$. An integral part of this process was the identification of key benefits and risks from all available data sources potentially associated with $\mathrm{CP}$, within this disease context. At the current time, the availability of data from comparative studies pertaining to these key outcomes (as per the value tree) was limited, which precluded further quantitative analysis. However, the identification of key benefits and risks within this framework allows the incorporation of further data relating to these outcomes to be incorporated as and when this becomes available.

Whilst a systematic benefit-risk assessment could not be undertaken at the current time due to the lack of data, we discuss the benefit and risk data available to date. Whilst uncontrolled case series have suggested positive findings with $\mathrm{CP}$, results from these studies are very difficult to interpret, given the limitations previously discussed. We identified only four controlled studies, inclusive of one RCT and three controlled non-randomised studies. In the RCT, findings for the primary outcome of time to clinical improvement amongst the 103 patients included were not statistically significant, however it is acknowledged that the study may have been underpowered due to its early termination. It is of note that a statistically significant result for this outcome was obtained when the intervention group was restricted to patients with severe disease only (but not life-threatening disease) compared to the control group. This may reflect the administration of this therapy earlier in the disease process, when it is considered that antibody-based therapies work best [36, 37]. 
medRxiv preprint doi: https://doi.org/10.1101/2020.08.24.20180729; this version posted August 26, 2020. The copyright holder for this

preprint (which was not certified by peer review) is the author/funder, who has granted medRxiv a license to display the preprint in It is made available under a CC-BY-ND 4.0 International license .

Nevertheless, the overall median time between onset of symptoms and randomisation was 30 days, and the authors state that it is unclear whether earlier treatment would have resulted in greater benefit [24]. The question of whether earlier treatment may have resulted in greater benefit also applies to study findings by Zeng et al, in which the median days to treatment was 21.5 days [26]. In the study by Hegerova et al, the median time from hospitalization to CP was earlier at 2 days (IQR 1-4.3), however the study does not report on the median time from onset of symptoms [25]. The mean time from onset of illness to $\mathrm{CP}$ transfusion amongst the ten patients who received $\mathrm{CP}$ in the study by Duan et al was 16.5 days [27].

Based on these studies, evidence of benefit at the current time is limited. The results from the study by Li et al may suggest some shortening of the time to clinical improvement amongst patients with severe disease, but this possible signal is based on a small subset of patients $(n=23)$ and would require further investigation in adequately powered randomised controlled studies. However statistically significantly higher viral clearance rates seen at 24, 48 and 72 hours were observed amongst patients who received $\mathrm{CP}$, which would suggest that viral clearance may be achieved before clinical improvement is observed [24]. Interpretation of study findings from the three controlled non-randomised studies is limited by the lack of randomization, small patient numbers involved, and confounding by additional risk factors including co-administration of other COVID-19 treatments.

The value tree identified potential risks associated with CP. TACO is considered to be one of the most common serious adverse effects of transfusion [34] and it is possible that elderly patients with acute lung injury may be at increased susceptibility [34]. Overall, limited safety data was available from the four controlled studies identified. Two patients experienced transfusion-related adverse events in the study by Li et al (3.8\%) and both patients recovered following supportive treatment [24]. This figure would appear to be consistent with reported incidence rates of TACO and TRALI previously published, in which active surveillance estimates of TRALI were $\sim 0.1 \%$ of transfused patients but up to $5 \%$ to $8 \%$ in groups of intensive care unit populations [38]. The authors of the study by Hegerova et al stated there did not appear to be an increased risk of venous thromboembolism in CP patients, although the incidence was high in both groups despite heparin prophylaxis (20\% at 14 days post follow up) [25].

An additional potential risk of CP transfusion is the development of ADE which has been previously recognised in other viral illnesses $[32,33]$. A further related risk is complement- 
medRxiv preprint doi: https://doi.org/10.1101/2020.08.24.20180729; this version posted August 26, 2020. The copyright holder for this preprint (which was not certified by peer review) is the author/funder, who has granted medRxiv a license to display the preprint in It is made available under a CC-BY-ND 4.0 International license .

dependent antibody enhancement, which has also been seen in other viral illnesses such as Ebola, and it is not yet known whether these play a role in COVID-19 [34].

A limitation of this study was that there was insufficient data to produce a data summary table, or to perform any quantitative analysis, therefore we were unable to complete all stages included in the BRAT methodology. The only RCT included in this assessment was probably underpowered to detect the primary outcome of time to improvement, and overall showed no statistically significant improvement amongst patients who received $\mathrm{CP}$. There was also very little risk data amongst controlled study populations, and it acknowledged that the role of ADE in COVID-19 has yet to be investigated. However, we have presented a value tree inclusive of key benefits and risks which can be used to guide further assessments, as additional data becomes available. As per the eligibility criteria for BRAT methodology, only peer reviewed published papers have been included in this assessment, however it is acknowledged that further studies containing comparative data are currently available as pre-prints and therefore have not yet been peer reviewed. One of these studies is an RCT in which CP was compared to standard of care therapy amongst patients hospitalized for COVID-19 in the Netherlands [39]. The primary endpoint was day-60 mortality and key secondary endpoints included hospital stay and WHO 8-point disease severity scale improvement on day 15 . This study was terminated prematurely after 86 patients had been enrolled (planned sample size was 426 patients). Patients were noted to have had COVID-19 related symptoms for a median of 10 days (IQR 6 - 15) and admitted for median of 2 days (IQR 1 - 3 days). Of the patients who had been enrolled, the majority for whom blood samples were available $(n=66)$ already had high neutralizing antibody titres which were comparable to the 115 recovered donors screened for CP plasma donation. As a result of this, the decision was made to terminate the study, as it was considered very unlikely that the overall study population would benefit from CP therapy without a change in the patient recruitment strategy. No statistically significant differences in mortality (adjusted OR $0.95,95 \%$ CI $0.20-4.67, p=0.95$ ) or improvement in the day-15 disease severity (adjusted OR 1.30, 95\% CI $0.52-3.32, \mathrm{p}=0.58$ ) was observed when the study was suspended.

A further non-randomised controlled study in the U.S by Liu et al compared outcomes of 39 hospitalized patients with severe to life-threatening COVID-19 who received CP transfusions with a cohort of retrospectively propensity score-matched controls [30]. Patients were evaluated for supplemental oxygen requirements and survival at days 1,7 , and 14 posttransfusion. The median duration of symptoms prior to initial presentation was 7 days (IQR 
medRxiv preprint doi: https://doi.org/10.1101/2020.08.24.20180729; this version posted August 26, 2020. The copyright holder for this

preprint (which was not certified by peer review) is the author/funder, who has granted medRxiv a license to display the preprint in It is made available under a CC-BY-ND 4.0 International license.

0-14) and the median time between admission and transfusion was 4 days (IQR 1- 7) days. Matching of controls was performed on multiple factors including administration of hydroxychloroquine and azithromycin, intubation status and duration, length of hospital stay and oxygen requirement on the day of transfusion. Control patients were matched to plasma recipients by length of stay prior to transfusion. Improvement of clinical symptoms, as assessed by need for respiratory support at day 14, included 39 participants in the intervention group and 156 participants in the control group. Clinical condition had worsened in $18.0 \%$ of the plasma patients and $24.3 \%$ in the control patients $(p=0.167)$. The adjusted odds ratio for worsening oxygenation on day 14 was 0.86 (95\% CI: $0.75-0.98, p=0.028)$. On days 1 and 7, the plasma group also showed a reduction in the proportion of patients with worsened oxygenation status, but the group difference did not reach statistical significance. Overall, $12.8 \%$ of plasma recipients and $24.4 \%$ of the control patients died and $71.8 \%$ and $66.7 \%$ had been discharged, respectively. Overall improved survival was observed for the plasma group (log-rank test: $\mathrm{p}=0.039$ ). In a Cox regression (time to event) analysis, $\mathrm{CP}$ transfusion was significantly associated with improved survival in non-intubated patients (adjusted hazard ratio (HR) 0.19, (95\% CI: $0.05-0.72), p=0.015)$, which was not observed in intubated patients (adjusted HR 1.24, 95\% CI $(0.33-4.67, \mathrm{p}=0.752)$ ). In this study, the authors found no evidence that the effect of CP depended on the duration of symptoms ( $p=0.19$ for the plasma by duration interaction). No significant transfusion-related morbidity or mortality were observed in the $\mathrm{CP}$ recipient cohort. It is of note that results were adjusted for hydroxychloroquine and azithromycin, intubation status and duration, length of hospital stay, and oxygen requirement on the day of transfusion. However, results were not adjusted for age and gender, and the sample size was too small to allow for further sub-group analyses.

Complete data from these two studies will be included in subsequent $\mathrm{CP}$ benefit risk assessments, following their publication.

\section{Conclusion:}

There was insufficient evidence from controlled studies to complete a data summary table for a systematic benefit-risk assessment of the use of $\mathrm{CP}$ at the current time, and as such a benefit-risk conclusion could not be made. It is of note that whilst uncontrolled case series have suggested positive findings with $\mathrm{CP}$, results from these studies are very difficult to interpret. We provide a framework in which anticipated key benefits and risks have been identified, which can be updated when further data that have an impact on the benefit- risk assessment become available. 
medRxiv preprint doi: https://doi.org/10.1101/2020.08.24.20180729; this version posted August 26, 2020. The copyright holder for this preprint (which was not certified by peer review) is the author/funder, who has granted medRxiv a license to display the preprint in It is made available under a CC-BY-ND 4.0 International license .

\section{References}

1. WHO. WHO declares COVID-19 a pandemic. 2020.

2. Verity R, Okell LC, Dorigatti I, Winskill P, Whittaker C, Imai N et al. Estimates of the severity of coronavirus disease 2019: a model-based analysis. The Lancet Infectious diseases. 2020;20(6):66977. doi:10.1016/S1473-3099(20)30243-7.

3. EMA. First COVID-19 treatment recommended for EU authorisation. 2020.

4. EMA. EMA starts review of dexamethasone for treating adults with COVID-19 requiring respiratory support. 2020.

5. Mair-Jenkins J, Saavedra-Campos M, Baillie JK, Cleary P, Khaw F-M, Lim WS et al. The effectiveness of convalescent plasma and hyperimmune immunoglobulin for the treatment of severe acute respiratory infections of viral etiology: A systematic review and exploratory meta-analysis. Journal of Infectious Diseases. 2015;211(1):80-90. doi:http://dx.doi.org/10.1093/infdis/jiu396.

6. Sun M, Xu Y, He H, Zhang L, Wang X, Qiu Q et al. Potential effective treatment for COVID-19: systematic review and meta-analysis of the severe infectious disease with convalescent plasma therapy. International journal of infectious diseases : IJID : official publication of the International Society for Infectious Diseases. 2020. doi:10.1016/j.ijid.2020.06.107.

7. Joyner M. Expanded Access to Convalescent Plasma for the Treatment of Patients With COVID-19. 2020.

8. Commission E. An EU programme of COVID-19 convalescent plasma collection and transfusion. 2020.

9. Trials.gov C. Number of clinical studies involving convalescent plasma in COVID 19. 2020.

10. (NHSBT) NBaT. Convalescent plasma trials - Information about the two clinical trials: REMAP-CAP and RECOVERY. 2020.

11. Rajendran K, Krishnasamy N, Rangarajan J, Rathinam J, Natarajan M, Ramachandran A. Convalescent plasma transfusion for the treatment of COVID-19: Systematic review. J Med Virol. 2020. doi:10.1002/jmv.25961.

12. Valk SJ, Piechotta V, Chai KL, Doree C, Monsef I, Wood EM et al. Convalescent plasma or hyperimmune immunoglobulin for people with COVID-19: a rapid review. Cochrane Database of Systematic Reviews. 2020;2020(5). doi:http://dx.doi.org/10.1002/14651858.CD013600.

13. Osborne V, Davies M, Roy D, Tescione F, Shakir SAW. Systematic benefit-risk assessment for buprenorphine implant: a semiquantitative method to support risk management. BMJ Evid Based Med. 2020. doi:10.1136/bmjebm-2019-111295.

14. Nixon R, Dierig C, Mt-Isa S, Stockert I, Tong T, Kuhls S et al. A case study using the PrOACT-URL and BRAT frameworks for structured benefit risk assessment. Biom J. 2016;58(1):8-27. doi:10.1002/bimj.201300248.

15. PROTECT. BRAT (Benefit-Risk Action Team). 2015.

16. Davies M, Osborne V, Lane S, Roy D, Dhanda S, Evans A et al. Remdesivir in Treatment of COVID19: A Systematic Benefit-Risk Assessment. Drug Saf. 2020;43(7):645-56. doi:10.1007/s40264-02000952-1.

17. Osborne V, Davies M, Lane S, Evans A, Denyer J, Dhanda S et al. Lopinavir-Ritonavir in the Treatment of COVID-19: A Dynamic Systematic Benefit-Risk Assessment. Drug Saf. 2020. doi:10.1007/s40264-020-00966-9.

18. Shen C, Wang Z, Zhao F, Yang Y, Li J, Yuan J et al. Treatment of 5 Critically III Patients With COVID19 With Convalescent Plasma. Jama. 2020;323(16):1582-9. doi:10.1001/jama.2020.4783.

19. Ahn JY, Sohn Y, Lee SH, Cho Y, Hyun JH, Baek YJ et al. Use of Convalescent Plasma Therapy in Two COVID-19 Patients with Acute Respiratory Distress Syndrome in Korea. Journal of Korean medical science. 2020;35(14):e149. doi:10.3346/jkms.2020.35.e149.

20. Ye M, Fu D, Ren $Y$, Wang F, Wang D, Zhang F et al. Treatment with convalescent plasma for COVID-19 patients in Wuhan, China. J Med Virol. 2020. doi:10.1002/jmv.25882. 
medRxiv preprint doi: https://doi.org/10.1101/2020.08.24.20180729; this version posted August 26, 2020. The copyright holder for this preprint (which was not certified by peer review) is the author/funder, who has granted medRxiv a license to display the preprint in

It is made available under a CC-BY-ND 4.0 International license.

21. Zhang B, Liu S, Tan T, Huang W, Dong Y, Chen L et al. Treatment with convalescent plasma for critically ill patients with SARS-CoV-2 infection. Chest. 2020.

doi:http://dx.doi.org/10.1016/i.chest.2020.03.039.

22. Salazar E, Perez KK, Ashraf M, Chen J, Castillo B, Christensen PA et al. Treatment of COVID-19 Patients with Convalescent Plasma. The American journal of pathology. 2020.

doi:10.1016/j.ajpath.2020.05.014.

23. Erkurt MA, Sarici A, Berber I, Kuku I, Kaya E, Özgül M. Life-saving effect of convalescent plasma treatment in covid-19 disease: Clinical trial from eastern Anatolia. Transfusion and apheresis science : official journal of the World Apheresis Association : official journal of the European Society for Haemapheresis. 2020:102867. doi:10.1016/j.transci.2020.102867.

24. Li L, Zhang W, Hu Y, Tong X, Zheng S, Yang J et al. Effect of Convalescent Plasma Therapy on Time to Clinical Improvement in Patients With Severe and Life-threatening COVID-19: A Randomized Clinical Trial. JAMA. 2020. doi:http://dx.doi.org/10.1001/iama.2020.10044.

25. Hegerova L, Gooley T, Sweerus KA, Maree CL, Bailey N, Bailey M et al. Use of Convalescent Plasma in Hospitalized Patients with Covid-19 - Case Series. Blood. 2020. doi:10.1182/blood.2020006964.

26. Zeng QL, Yu ZJ, Gou JJ, Li GM, Ma SH, Zhang GF et al. Effect of Convalescent Plasma Therapy on Viral Shedding and Survival in Patients With Coronavirus Disease 2019. The Journal of infectious diseases. 2020;222(1):38-43. doi:10.1093/infdis/jiaa228.

27. Duan K, Liu B, Li C, Zhang H, Yu T, Qu J et al. Effectiveness of convalescent plasma therapy in severe COVID-19 patients. Proceedings of the National Academy of Sciences of the United States of America. 2020;117(17):9490-6. doi:10.1073/pnas.2004168117.

28. Duan K, Liu B, Li C, Zhang H, Yu T, Qu J et al. Effectiveness of convalescent plasma therapy in severe COVID-19 patients: Supplementary Materials. Proceedings of the National Academy of Sciences. 2020;117(17):9490-6. doi:10.1073/pnas.2004168117.

29. Joyner M. Safety Update: COVID-19 Convalescent Plasma in 20,000 Hospitalized Patients. 2020. 30. Liu STH LH, Baine I, Wajnberg A, Gumprecht JP, Rahman F et al. Convalescent plasma treatment of severe COVID-19: A matched control study. medRxiv preprint server. 2020.

31. Pandey S, Vyas GN. Adverse effects of plasma transfusion. Transfusion. 2012;52 Suppl 1:65S-79S. doi:10.1111/j.1537-2995.2012.03663.x.

32. Smatti MK, Al Thani AA, Yassine HM. Viral-Induced Enhanced Disease Illness. Front Microbiol. 2018;9:2991. doi:10.3389/fmicb.2018.02991.

33. Taylor A, Foo SS, Bruzzone R, Dinh LV, King NJ, Mahalingam S. Fc receptors in antibodydependent enhancement of viral infections. Immunol Rev. 2015;268(1):340-64.

doi:10.1111/imr.12367.

34. Dzik S. COVID-19 Convalescent Plasma: Now Is the Time for Better Science. Transfusion medicine reviews. 2020. doi:10.1016/j.tmrv.2020.04.002.

35. Casadevall A, Pirofski LA. The convalescent sera option for containing COVID-19. The Journal of clinical investigation. 2020;130(4):1545-8. doi:10.1172/JCI138003.

36. Casadevall A, Joyner MJ, Pirofski L-A. A Randomized Trial of Convalescent Plasma for COVID-19-

Potentially Hopeful Signals. JAMA. 2020. doi:http://dx.doi.org/10.1001/jama.2020.10218.

37. Casadevall A, Scharff MD. Return to the past: the case for antibody-based therapies in infectious diseases. Clinical infectious diseases : an official publication of the Infectious Diseases Society of America. 1995;21(1):150-61. doi:10.1093/clinids/21.1.150.

38. Roubinian N. TACO and TRALI: biology, risk factors, and prevention strategies. Hematology Am Soc Hematol Educ Program. 2018;2018(1):585-94. doi:10.1182/asheducation-2018.1.585.

39. Gharbharan A, Jordans CCE, GeurtsvanKessel C, den Hollander JG, Karim F, Mollema FPN et al. Convalescent Plasma for COVID-19. A randomized clinical trial. medRxiv : the preprint server for health sciences. 2020:2020.07.01.20139857. doi:10.1101/2020.07.01.20139857. 
medRxiv preprint doi: https://doi.org/10.1101/2020.08.24.20180729; this version posted August 26, 2020. The copyright holder for this

preprint (which was not certified by peer review) is the author/funder, who has granted medRxiv a license to display the preprint in It is made available under a CC-BY-ND 4.0 International license.

\section{Footnotes}

\section{Contributorship statement}

MD assisted with study design, literature searching, identified outcomes of interest, constructed the value tree and wrote the first draft of the manuscript. SD, DR, SL, JD and AE assisted with study design, literature searching and data extraction. VO and SAWS assisted with the concept, study design and manuscript revisions. All authors reviewed, contributed to revisions and approved the manuscript and accept full responsibility for its overall content.

\section{Data sharing statement}

Data used in this analysis are available from the references supplied.

\section{Ethics approval}

This study was conducted in accordance with international ethical guidelines. Ethics approval was not required for this study.

\section{Funding}

The Drug Safety Research Unit (DSRU) is an independent academic institution which works in association with the University of Portsmouth. No funding was received for this project.

\section{Conflicts of interest/Competing interests}

The Drug Safety Research Unit is an independent charity (No. 327206), which works in association with the University of Portsmouth. It receives unconditional donations from pharmaceutical companies. The companies have no control on the conduct or the publication of the studies conducted by the DSRU. Miranda Davies, Samantha Lane, Alison Evans, Jacqueline Denyer, Sandeep Dhanda, Debabrata Roy, Vicki Osborne, Saad Shakir have no conflicts of interest to declare.

\section{Transparency statement}

The lead author affirms that the manuscript is an honest, accurate, and transparent account of the study being reported; no important aspects of the study have been omitted. All authors reviewed, contributed to revisions and approved the manuscript and accept full responsibility for its overall content. 
medRxiv preprint doi: https://doi.org/10.1101/2020.08.24.20180729; this version posted August 26, 2020. The copyright holder for this preprint (which was not certified by peer review) is the author/funder, who has granted medRxiv a license to display the preprint in

perpetuity.
It is made available under a CC-BY-ND 4.0 International license .

\section{Consent to participate}

Not applicable

\section{Consent for publication}

Not applicable

\section{Availability of data and material (data transparency)}

Data used in this analysis are available from the references supplied.

\section{Code availability (software application or custom code)}

Not applicable

\section{Patient consent}

Not required 


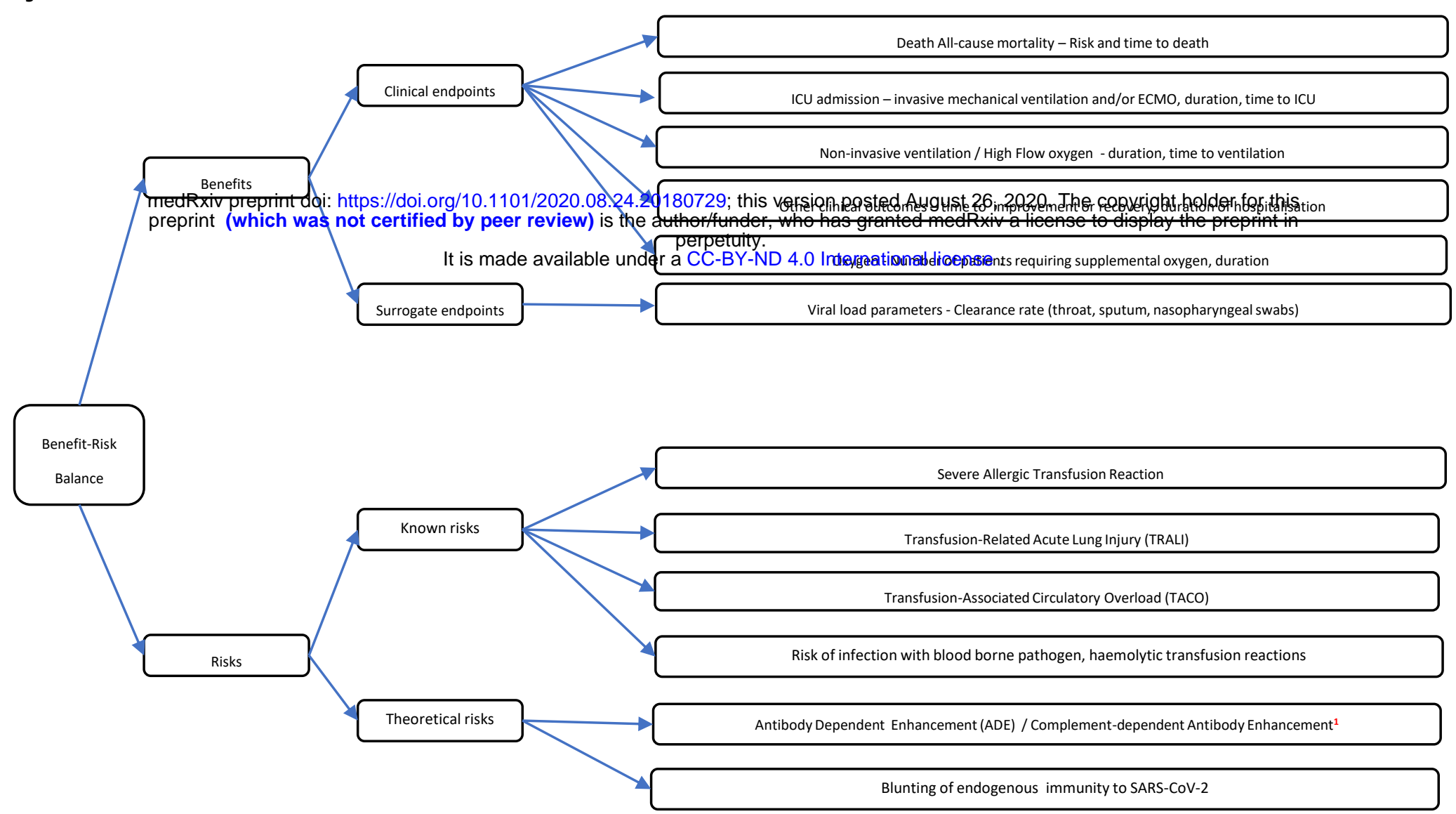

Both benefits and risks have been ranked according to perceived clinical significance.

${ }^{1} \mathrm{ADE}$ is a potential risk based on knowledge from other viral illnesses - it is not currently unknown whether ADE plays a role in COVID-19 (ECMO=Extra Corporeal Membrane Oxygenation; ICU=Intensive Care Unit) 